\title{
The Effect of Family Ownership on the Relationship Between Aggressive Financial And Tax Reporting: Evidence From 10 Asian Countries
}

\author{
Sabar Warsini ${ }^{1}$, Sylvia Veronica Siregar ${ }^{2}$, Dwi Martani ${ }^{3}$, Ludovicus Sensi W. ${ }^{4}$ \\ \{sabar.warsini@akuntansi.pnj.ac.id ${ }^{1}$, sylvia.veronica@ui.ac.id ${ }^{2}$, dwimartani@yahoo.com ${ }^{3}$, \\ lwondabio@gmail.com ${ }^{4}$ \} \\ Politeknik Negeri Jakarta, Indonesia \\ Universitas Indonesia, Indonesia ${ }^{2,3,4}$
}

\begin{abstract}
This research aims to investigate the nature of the relationship between aggressive financial and tax reporting, and the influence of family ownership upon that relationship. Using cross-country data of public companies listed on the stock exchanges of 10 countries in Asia, this study finds that aggressive financial reporting is associated positively with aggressive tax reporting and is reciprocal in nature, indicating that managers may no longer face a trade-off between the two. It is evident that managers have conducted aggressive financial and tax reporting simultaneously for the same reporting period. This aggressive reporting tendency is influenced by the characteristics of the company. Companies controlled by families tend to conduct less simultaneous aggressive financial and tax reporting for the same reporting period than others. These findings prove that the existence of family control in public companies does not encourage managers to conduct simultaneous aggressive financial and tax reporting in the same reporting period.
\end{abstract}

Keywords: aggressive financial reporting, aggressive tax reporting, family ownership

\section{Introduction}

Positive accounting theory, Scott [1] states that GAAP provides flexibility in choosing accounting policies/methods in financial reporting practices so as to encourage management to conduct earnings management to meet certain objectives. With regard to tax reporting, Lim [2] states that tax regulations allow management to make taxable income arrangements by utilizing certain the loophole of tax regulation.

To meet certain objectives related to the measurement of financial performance, there is a tendency for management to report higher accounting profits, known as aggressive financial reporting. On the other hand, related to the obligation to pay taxes, there is also a tendency for management to report lower fiscal profits, which is known as aggressive tax reporting [3]. The tendency of management to undertake aggressive financial reporting and aggressive tax reporting has been proven in two separate research areas, namely earnings management research and tax avoidance research.

Initially, earnings management research widely explored the ways of manipulating accounting profits and what the underlying motives for this were [4] [5] [6]. Further 
development of earnings management research was linked to corporate governance mechanisms and it became evident that corporate governance mechanisms reflected in corporate and institutional characteristics influence earnings management and its implications [7] [8] [9].

In line with earnings management research area, in aggressive tax research has also found widespread evidence of tax avoidance practices, their underlying motives, and the implications of tax evasion [10] [11]. The conventional view holds that management conducts tax avoidance for efficiency purposes. This has an impact on improving the prosperity of the owner, but the agency theory perspective developed by Desai [12] and [11] states that management could avoid taxes to make personal gain. Therefore, the development of tax avoidance research further considers corporate governance mechanisms, and it is evident that tax avoidance and its implications are influenced by corporate governance mechanisms [13] [14] [15] [16] [17].

Although the topic of aggressive reporting has been explored separately very widely, investigation of the relationship between aggressive financial and tax reporting is still very limited. An effort to prove the relationship between aggressive financial and tax reporting is very important so that it can answer the question "Can management do both within the same reporting period?"

In the view of nonconforming book-tax reporting, the difference in rules between accounting standards and tax laws allows management to conduct aggressive reporting through transaction engineering, which treats accounting rules and tax rules differently, and is called book-tax nonconformity transactions [18]. This finding is reinforced by [19] who found that US companies charged with creating tax shelters were also proved to have managed financial reporting through discretionary accruals.

Other empirical evidence that reinforces the notion that firms no longer face a trade-off between aggressive financial and tax reporting was found by Frank et al. [3] in the examination of the relationship between aggressive financial reporting and aggressive tax reporting - regressing aggressive tax reporting on aggressive financial reporting (and vice versa). Frank et al. [3] found a strong positive relationship between these two constructs, even after controlling for tax planning and earnings management incentives and other firm-specific characteristics. They suggest that their research focuses only on the direction of the relationship between aggressive tax and financial reporting, so they provide opportunities for further research development to explore various characteristics that affect the positive relationship between aggressive tax and financial reporting.

This research intends to extend the findings of Frank et al. [3] and Noh et al. [20] by testing the relationship between aggressive financial and tax reporting using cross-country data. It was conducted on public companies outside the US, using public company data from Asian countries. Public companies in Asia have different characteristics to those in the US, so to establish whether the behavior of aggressive reporting is in line with the findings from the US, this research begins by testing the relationship between aggressive tax and financial reporting. Furthermore, as an extension of Frank et al. [3] research, this study tests the influence of family ownership on the relationship between aggressive financial and tax reporting. It is known that public companies in Asia have specific ownership structure characteristics i.e.: there is a dominance of family ownership [21] [22]. Related to these specific ownership structure characteristics arises the research question: "How family ownership influences to the relationship between aggressive financial and tax reporting? Through this research, the influence of family ownership on the relationship between aggressive financial and tax reporting will provide evidence for whether there is a difference 
between the aggressive reporting behavior of companies controlled by family ownership and those without family control.

Understanding the relationship between aggressive tax and financial reporting, and the influence of corporate characteristics on this relationship, will benefit some parties. The results of this study provide important information for investors on being more careful in using profit information as a basis for decision making. The existence of the tendency of company management towards aggressive financial and tax reporting will result in a lower quality of profit information, which may mislead investors in decision making.

The results of this study are expected to provide input for regulators, for example evidence that there is a tendency for managers towards aggressive simultaneous financial and tax reporting, which indicates the existence of nonconformity between accounting standards with tax regulations. This greater nonconformity provides a loophole for managers to conduct nonconforming transactional engineering, potentially resulting in a loss of tax revenue and lower quality of financial statements. This should be a concern for the tax authorities, stock exchange authorities, and investors. Atwood et al., [15] state that higher compliance between accounting standards and tax regulations can mitigate opportunistic management actions, and consequently improve the transparency of overall company performance.

This study will contribute to the development of the literature in at least two dimensions. First, it examines the relationship between aggressive financial and tax reporting with crossborder data in Asia in order to broaden the empirical evidence of aggressive reporting behavior by management. Similar studies are still very limited ie: Frank et al,. [3], Heltzer et al., [23], Noh et al. [20] and have been conducted on public companies in the US. Second, the test of the relationship between aggressive financial and tax reporting in this study considers family controls which are specific to the structure of public company ownership in Asia, thus providing new evidence that a company's specific characteristics affect aggressive reporting behavior.

\section{Literature Review}

\subsection{Relationship Between Aggressive Tax Reporting And Aggressive Financial Reporting.}

Book income and taxable income reporting have different rules and objectives. Book income reports are prepared under generally accepted accounting standards (GAAP), with the aim of providing financial performance information to investors and other stakeholders, while taxable income reports are prepared based on taxation and are intended for the tax authorities as the basis for determining the tax payable by the company.

To meet certain objectives related to the measurement of financial performance, there is a tendency for management to report higher accounting profits, known as aggressive financial reporting. On the other hand, related to the obligation to pay taxes, there is also a tendency for management to report lower fiscal profits, which is known as aggressive tax reporting. Can management do both within the same reporting period?

In the view of nonconforming book-tax reporting, the difference in rules between accounting standards and tax laws allows management to conduct aggressive reporting through transaction engineering, which treats accounting rules and tax rules differently, and is called book-tax nonconformity transactions [18]. This strategy makes the relationship between aggressive tax reporting and aggressive financial reporting complementary [3]. This complementary relationship shows that the two are not mutually exclusive, so they can be used by management in order to maximize their profits. 
There exist management opportunities to engineer non-conforming book-tax transactions and to maximize profits, encouraging companies that have undertaken aggressive financial reporting to undertake aggressive tax reporting, and vice versa. The underlying argument is that if the company only makes aggressive financial reporting without aggressive tax reporting, then the goal of obtaining a good financial performance assessment is achieved, but that the company assumes the risk of paying high taxes. Conversely, if the company only makes aggressive tax reporting without aggressive financial reporting, then only the objective of tax minimization is achieved, carrying the risk of poor performance appraisal.

Based on the concept of nonconforming book-tax reporting, and arguing for the tendency of aggressive reporting behavior by management, the first hypothesis developed in this research is:

H1 : Aggressive financial reporting is positively related to aggressive tax reporting and vice versa.

\subsection{Influence of Family Control on the Relationship between Aggressive Financial and Tax Reporting}

Claessens et al. [21] find the phenomenon of the public shareholding of public companies in Asia leads to concentrated ownership, with the majority of shareholders being families. Based on the perspective of agency theory, the existence of family owners as insider investors holding the greatest share of the ownership structure of public companies produces two theories, alignment theory and entrenchment theory, as developments of agency theory [24].

In the view of alignment theory, greater family ownership with insider investors will have an impact on the existence of the alignment of interests with minority shareholders. Families will organize management more on the basis of competency considerations rather than affiliation factor considerations. They will prioritize business continuity and long-term performance, thereby encouraging management to not act opportunistically. On the other hand, in the view of entrenchment theory, greater family ownership with insider investors will have an impact on the expropriation of minority shareholders by placing affiliated people in the company and then encouraging management to adopt policies that only benefit their own interests.

Earlier studies that examined the direct effect of family ownership on aggressive financial reporting found two directions, partially supporting alignment theory [25]; others supported entrenchment theory by Jiang et al., 2011 and Zaluki et al. In line with the results of the study of the effect of family ownership on aggressive financial reporting, studies of the direct effect of family ownership on aggressive tax reporting have also found a duality of direction, some supportive of alignment theory [14], some of the entrenchment theory.

Referring to alignment and entrenchment theory, the uniqueness of family enterprises and previous research outcomes that examine the direct effects of family ownership on aggressive reporting, it can be argued that the presence of family ownership may encourage aggressive reporting or otherwise may not do this. Families in public companies will influence the tendency of aggressive reporting behavior. The chances are that families will encourage or restrict management to undertake aggressive financial and tax reporting simultaneously. Therefore the second hypothesis developed for this research is:

$\mathrm{H} 2$ : Family-controlled firms affecting the positive reciprocal relationship between aggressive financial and tax reporting. 


\section{Method}

\subsection{Data and Sample Selection}

The research area covers all listed public companies on the capital markets of 10 countries in Asia which was the object of an assessment of the implementation of corporate governance by Credit Lyonnais Securities Asia (CLSA), namely China, Hong Kong, India, Indonesia, South Korea, Malaysia, Philippines, Singapore, Taiwan, and Thailand. The analytical unit uses the firm-year, with analysis from 2012 through to 2014. Financial data, and information on the family were obtained from Thomson Reuter Datastream sources. The control variables related to aggressive reporting are GDP, statutory tax rate, and investor protection, using data sources from the global competitiveness report published by the World Economic Forum.

The total of the firm years is 45,775 then the sample selection is done by excluded: 1 ) financial industry $(10,008)$ because this industry is highly-regulated industry; 2) real estate industry $(2,211)$ because this industry has their own accounting rules; 3) mining, oil, gas, construction, shipping, aviation or transportation industries $(5,662)$ because they have different tax arrangements to other industries (lex specialis); 4) Not availability of financial data and other data required to measure all the variables used in research $(16,371)$; and 5) Noncompliance with the number of observations per industry group to calculate aggressive financial and tax reporting variables (105). Industrial groups with annual observations of fewer than six firms are excluded from the sample. Grouping industries as the basis for aggressive reporting and industry specifications refer to the global industry classification standard (GICS) developed by Morgan Stanley Capital International (MSCI) and Standard \& Poors. The results of the sample selection procedure obtained by the final sample of 11,418 firm years.

\subsection{Research Models}

The model used to test the hypotheses developed in this study is OLS regression. Referring to Frank et al. [3], in order to examine the relationship between aggressive financial and tax reporting, and to examine how the influence of family control on the reciprocal relationship between the two types of aggressive reporting, two simultaneous regression equations are used, as follows:

AFRit $=\beta \mathrm{i}+\beta 1$ ATRit $+\beta 2$ FAMit $+\beta 3$ (ATRit*FAMit $)+\beta 4 \Delta$ MVEit $+\beta 5$ EPRESSit + $\beta 6 \Delta$ CFOit $+\beta$ 7SIZEit $+\beta 8$ LEVit $+\beta$ GDPit $+\beta 10$ INPROTECTit $+\varepsilon$ it $\ldots$ (3.1).

And,

ATRit $=\alpha i+\alpha 1$ AFRit $+\alpha 2$ FAMit $+\alpha 3$ (AFRit $*$ FAMit $)+\alpha 4$ PTROAit $+\alpha 5$ NOLit + $\alpha 6$ FOREIGNit $+\alpha 7$ SIZEit $+\alpha 8$ LEVit $+\alpha 9$ STRit $+\alpha 10$ GDPit + eit...(3.2).

Aggressive Financial Reporting (AFR) uses the discretionary accruals of Jones [26] model, and the measure of Aggressive Tax Reporting (ATR) uses discretionary permanent book-tax differences model of Frank et al. [3]. Family Control (FAM) is the percentage of shares owned by the family according to the definition of Anderson et al. [27]. Referring to Martínez et al. (2018), public companies are controlled by families when family ownership is $50 \%$ or higher. The control variable of the family in this study is a dummy variable with a value of 1 if the family ownership is $50 \%$ or higher, and 0 otherwise.

The aggressive financial reporting motivation control variables are: Change in the market value of equity ( $\triangle \mathrm{MVE}$ ) is referring to Frank et al. [3], Earnings Pressure (EPRESS) is referring to Yin and Cheng [24], and Change in the operating cash flow $(\triangle C F O)$ is measured by referring Mills and Newberry [28]. The control variables of aggressive tax reporting 
motivation are: Pre-tax rate of return on investment (PTROA), Company's loss (NOL) and foreign income (FOREIN), the measure of these third variables refers to Frank et al. [3].

We include Company's size (SIZE) and Company's leverage (LEV) as a company characteristic control variables as has been widely used in previous studies. We control for state characteristic applied: Statutory Corporate tax rate (STR), gross domestic product (GDP), and a score of investor protection (INPROTECT). In general these variables describe the characteristics of a country that has been widely used as control variables by the previous cross country research.

\section{Discussion}

Table 1 (in appendix 1) presents the descriptive statistics, which provide an overview of the sample profiles and research variables. AFR has an average of 0.0022 , the positive value for the average AFR shows that the sample company is involved in aggressive financial reporting with a pattern of increasing income. The average value of ATR for the entire sample is 0.0032 , the average positive ATR value indicates that on average the sample company performs aggressive tax reporting actions by reporting lower taxable income compared to book income. Family ownership plays a unique role in the ownership structure of public companies in Asia.

The first hypothesis (H1) suggests that aggressive financial reporting is positively related to aggressive tax reporting, and vice versa. We first compute the Pearson correlation between AFR and ATR. The correlation results (untabulated) obtained show that AFR and ATR are significantly correlated in the positive direction, with a correlation coefficient of 0.2012 , significant at the level of $\alpha=5 \%$. Correlation analysis shows only a two-way relationship between AFR and ATR, without considering the control of other variables.

Further testing is performed by regressing AFR to ATR and vice versa, each controlled by the AFR and ATR incentive variables, using regression models (3.1) and (3.2). The regression results of both models are presented in Table 2 (in Appendix 2).

In table 2. column 1 shows evidence that AFR as a dependent variable and ATR as an independent variable have a positive ATR coefficient of 0.1704 with a probability t-stat of 0,000 , with significance at the level of $\alpha=1 \%$. In column 3, the regression test results with ATR as a dependent variable and AFR as an independent variable show a positive AFR coefficient of 0.0851 with a probability t-stat 0,000 with significance at the level of $\alpha=1 \%$. The results of this regression test prove that there is a positive and significant relationship between AFR with ATR, and vice versa.

The results of testing the relationship between AFR and ATR by using the correlation analysis and the regression test, are overall consistent, in that AFR and ATR have a significant positive and reciprocal relationship. Thus the first hypothesis can be proved, that a company undertakes aggressive financial and tax reporting for the same reporting period. Both types of aggressive reporting are not mutually limiting, but are simultaneous. The test results are in line with Frank et al. [3] and Noh et al. [20]. Company management carries out aggressive reporting of both book income and taxable income to maximize profits; that is, it obtains a good performance appraisal while simultaneously making tax savings. This research result suggests that aggressive reporting behavior may be a pervasive trait in tax and financial reporting through nonconformity book-tax transactions arrangement [18].

$\triangle \mathrm{MVE}, \mathrm{EPRESS}$, and $\triangle \mathrm{CFO}$ are the aggressive financial reporting incentive variables. The results of the tests found that changes in the market value of equities ( $\triangle \mathrm{MVE}$ ) have a positive effect on AFR indicating that firms with greater growth in the market value of their 
equities tend towards aggressive financial reporting. Fluctuations in cash flow $(\triangle \mathrm{CFO})$ has a negative effect on AFR indicating that firms experiencing greater fluctuations in cash flow tend not to do aggressive financial reporting, these results are in line with the findings of Yin and Cheng, Mills and Newberry [28], and Frank et al. [3].

PTROA, NOL and FOREIGN are aggressive tax reporting incentive variables. The test results found that companies that have income from other countries (FOREIGN) have a positive effect on ATR. These findings indicate that companies are increasingly aggressive in reporting taxable income if they have income from other countries. The results of this study are in line with those of Frank et al. [3], and Dharmapala and Riedel [13], who found that multi-national companies tend to conduct income shifting to reduce the overall corporate tax burden. Not supported Frank et al. [3] this study can not prove the influence of PTROA and NOL on aggressive tax reporting.

Furthermore, to prove the effect of FAM on the reciprocal relationship between ATR and AFR, the mutual influence between ATR and AFR was then tested, with FAM as moderation. The test results are presented in table 2, column 2, and column 4.

The coefficients of ATR*FAM and AFR* FAM are -0.1676 and -0.0778 respectively, significant at $\alpha=1 \%$. Based on the significance and the negative coefficient value, it is proven that the reciprocal positive relationship between ATR and AFR is lower in public companies controlled by families than in other public companies, so the second hypothesis is also proven. It can be interpreted that aggressive tax reporting firms tend not to perform aggressive financial reporting in the same reporting period, and instead aggressive financial reporting companies tend not to make aggressive tax reporting in the same reporting period. These findings prove that the existence of family control in public companies does not encourage managers to conduct simultaneous aggressive financial and tax reporting in the same reporting period.

It is possible the family shareholders in public companies are still related to the founder of the company and are also involved in the management of the company, so they have a good understanding of the company's business activities [29] Chi et al., [30] [27], and are more concerned about performance and reputation in the long term Amit and Villalonga. Based on the earnings management research perspective, the results of this study support the theory of alignment [25] and [31], which posits that earnings management is lower in family firms than in other types. In addition, based on the perspective of tax evasion research, this research result supports those of Chen et al. [14] and Heltzer et al. [23], who found that tax evasion in family companies is lower than in others. Chen et al. [14] reasoned that family companies avoid the reputational risk related to the sanctions of tax evasion more.

\section{Conclusion}

Using cross-country data of public companies listed on the stock exchanges of 10 countries in Asia, this research has found evidence that aggressive financial reporting is positively reciprocal and associated with aggressive tax reporting. These findings reinforce the nonconforming book-tax reporting theory, which states that company management no longer faces a trade-off in making aggressive reporting decisions. Simultaneous aggressive financial and tax reporting in the same reporting period has become widespread corporate management behavior in many countries. The behavior of simultaneous aggressive financial and tax reporting is influenced by corporate characteristics. In a family-controlled public company, the tendency of corporate management to display this behavior is lower than in other types of company. These results support the theory of alignment. 
Our results lead to a better understanding of nonconforming book-tax reporting and the impact of corporate characteristics on aggressive reporting behavior. We contribute to two streams of literature: studies that document the positive reciprocal relationship between aggressive financial and tax reporting, which initially used data from only one country, and studies of the impact of corporate characteristics on the tendency of management to undertake simultaneous aggressive financial and tax reporting for the same reporting period, as we know that the existing research examines the effect of corporate characteristics in this area separately.

Our research should be useful to regulators attempting to reduce corporate malfeasance, to investors in being more careful when using earnings report information and paying attention to corporate and institutional characteristics when investing, and to academics investigating aggressive reporting behavior. There are some limitations to this study, especially in the measurement of variables. It only uses a discretionary accruals approach to measure aggressive financial reporting and uses a discretionary book-tax differences approach to measure aggressive tax reporting, so future research should consider other measurements of aggressive financial reporting, such as real activity earnings management or discretionary revenue, and use real tax avoidance values, which are the result of tax authority investigations, in order to strengthen the evidence on nonconforming book-tax reporting behavior.

\section{Acknowledgment}

This research can be carried out with the support of various parties. Many thanks to Accounting Departement, Lecturers and Management of State Polytechnic of Jakarta, Lecturers of Accounting Departement of the University of Indonesia for support and discussion this research.

\section{References}

[1] Scott, W.R. Financial Accounting Theory, Seventh Edition, Ontario: Prentice-Hall, (2014).

[2] Lim, Y. Tax avoidance, cost of debt and shareholder activism: Evidence from Korea, Journal of Bank. Finance, vol. 35, no. 2, pp. 456-470 (2011).

[3] Frank, M.M., L. J. Lynch, and S. O. Rego. Tax reporting aggressiveness and its relation to aggressive financial reporting, Accounting Review, vol. 84, no. 2, pp. 467496 (2009).

[4] Siregar, S. V. and S. Utama. Type of earnings management and the effect of ownership structure, firm size, and corporate-governance practices: Evidence from Indonesia, The International Journal of Accounting, vol. 43, no. 1, pp. 1-27 (2008).

[5] Silva. A, M. Sancovschi, and A. Santos. The Opportunistic Approach of the Positive Accounting Theory Fails to Explain a Case Study: An Anomalous Situation? (2017).”

[6] Lassoued, N., M. B. R. Attia, and H. Sassi. Earnings management in Islamic and conventional banks: Does ownership structure matter? Evidence from the MENA region, The International Journal of Accounting, Audit and Tax (2018).

[7] Dechow, P., W. Ge, and C. Schrand. Understanding earnings quality: A review of the proxies, their determinants and their consequences, Journal of Account and Economics, vol. 50, no. 2-3, pp. 344-401(2010).

[8] Saleem, E. A. Ownership structure and earnings management: evidence from Jordan, International Journal of Accounting, vol. 24, no. 2, pp. 135-161 (2016).

[9] Lin, C. J., T. Wang, and C.-J. Pan. Financial reporting quality and investment decisions for family firms, Asia Pacific Journal of Management, vol. 33, no. 2, pp. 
499-532 (2016)."

[10] Gravelle, J. G. Tax havens: International tax avoidance and evasion, The National Tax Journal, pp. 727-753 (2009).

[11] Hanlon, M. and S. Heitzman. A review of tax research, Journal of Accounting and Economics, vol. 50, no. 2-3, pp. 127-178 (2010).

[12] Desai, M. A. The degradation of reported corporate profits, The Journal of Economics Perspectives, vol. 19, no. 4, pp. 171-192 (2005).

[13] Dharmapala, D. and N. Riedel. Earnings shocks and tax-motivated income-shifting: Evidence from European multinationals, Journal of Public Economics, Journal of Public Economics , vol. 97, pp. 95-107 (2013).

[14] Chen, S., X. Chen, Q. Cheng, and T. Shevlin. Are family firms more tax aggressive than non-family firms?, Journal of Financial Economics, vol. 95, no. 1, pp. 4161(2010)."

[15] Atwood, T. J., M. S. Drake, J. N. Myers, and L. A. Myers. Home country tax system characteristics and corporate tax avoidance: International evidence, The Accounting Review, vol. 87, no. 6, pp. 1831-1860 (2012).

[16] Richardson, G., R. Lanis, and S. C.-M. Leung. Corporate tax aggressiveness, outside directors, and debt policy: An empirical analysis, Journal of Corporate Finance, vol. 25, pp. 107-121 (2014).

[17] Moore, J. A. Empirical evidence on the impact of external monitoring on book-tax differences, Advances in Accounting, Incorporating Advances in International Accounting, vol. 28, no. 2, pp. 254-269 (2012).

[18] Badertscher, B.A., J. D. Phillips, M. Pincus, and S. O. Rego. Earnings management strategies and the trade-off between tax benefits and detection risk: To conform or not to conform?, The Accounting Review, vol. 84, no. 1, pp. 63-97 (2009).

[19] Wilson, R.J. "An examination of corporate tax shelter participants, The Accounting Review, vol. 84, no. 3, pp. 969-999 (2009).

[20] Noh, M., D. Moon, and A. Guiral. The Effect of Auditor-Provided Tax Services on Tax and Financial Reporting Aggressiveness, Advanced Science and Technology Letters, 47: 89-92 (2014).

[21] Claessens, S., S. Djankov, and L. H. P. Lang. The separation of ownership and control in East Asian corporations, Journal of Finance and Economics, vol. 58, no. 1-2, pp. 81-112 (2000).

[22] Hanazaki, M. and Q. Liu. Corporate governance and investment in East Asian firmsempirical analysis of family-controlled firms, Journal of Asian Ecocnomics, vol. 18, no. 1, pp. 76-97 (2007).

[23] Heltzer, W., M. P. Mindak, and S. W. Shelton. The relation between aggressive financial reporting and aggressive tax reporting: Evidence from ex-Arthur Andersen clients, Research in Accounting Regulation, vol. 24, no. 2, pp. 96-104 (2012).

[24] Yin-Hua, Y. and Woidtke, T. Commitment or Entrenchment?: Controlling Shareholders and Board Composition, Journal of Banking and Finance, 29: 1857-1885 (2005).

[25] Jaggi, B., S. Leung, and F. Gul. Family control, board independence and earnings management: Evidence based on Hong Kong firms, Journal of Accounting and Public Policy, vol. 28, no. 4, pp. 281-300 (2009).e.

[26] Jones, J.J. Earnings management during import relief investigations, Journal of Accounting Research, pp. 193-228 (1991).

[27] Anderson, R., G. S. Martin, and D. Reeb. Family ownership and financial 
misrepresentation, Working paper. Temple University (2015).

[28] Mills, L.F. and K. J. Newberry. The influence of tax and nontax costs on book-tax reporting differences: Public and private firms, Journal of the American Taxation Association, vol. 23, no. 1, pp. 1-19 (2001).

[29] Gaaya, S., N. Lakhal, and F. Lakhal. Does family ownership reduce corporate tax avoidance? The moderating effect of audit quality, Management Audit Journal, vol. 32, no. 7, pp. 731-744 (2017).

[30] Chi, C.W., K. Hung, H. W. Cheng, and P. T. Lieu. Family firms and earnings management in Taiwan: Influence of corporate governance, International Review of Economics and Finance, vol. 36, pp. 88-98 (2015).

[31] Masripah,M., V. Diyanty, and D. Fitriasari. Controlling Shareholder and Tax Avoidance: Family Ownership and Corporate Governance, Int. Res. J. Bus. Study., vol. 8 , no. 3 (2017).

\section{Appendix}

\section{Appendix 1}

Table 1

Descriptive statistics for the research variables

\begin{tabular}{|c|c|c|c|c|}
\hline Variable & Maximum & Minimum & Mean & Stdev \\
\hline AFR & 0.1409 & -0.1452 & 0.0022 & 0.0695 \\
\hline ATR & 0.1075 & -0.0795 & 0.0032 & 0.0444 \\
\hline FAM & 1 & 0 & 0.4323 & 0.3079 \\
\hline$\triangle \mathrm{MVE}$ & 0.4155 & 0.0026 & 0.1293 & 0.0765 \\
\hline EPRESS & 1 & 0 & 0.4420 & 0.4966 \\
\hline$\Delta \mathrm{CFO}$ & 0.1596 & -0.1557 & 0.0011 & 0.0827 \\
\hline PTROA & 0.175 & -0.1131 & 0.0441 & 0.0750 \\
\hline NOL & 1 & 0 & 0.1958 & 0.3988 \\
\hline FOREIGN & 1 & 0 & 0.4385 & 0.4963 \\
\hline LnSIZE & 13.0201 & 0.9419 & 9.1622 & 9.0120 \\
\hline LEV & 0.8262 & 0.1699 & 0.4810 & 0.1886 \\
\hline LnGDP & 4.6644 & 3.0640 & 4.1344 & 0.5498 \\
\hline STR & 0.4069 & 0.1650 & 0.2972 & 0.0885 \\
\hline INPROTECT & 5.6 & 3.7 & 4.6541 & 0.5733 \\
\hline $\mathrm{N}$ & \multicolumn{4}{|c|}{11,418} \\
\hline
\end{tabular}





\section{Appendix 2}

Table 2

Multivariate Regression Analysis of the Relation between AFR and ATR, moderated by FAM

\begin{tabular}{|c|c|c|c|c|c|c|c|c|c|}
\hline \multirow{3}{*}{$\begin{array}{l}\text { Independent } \\
\text { variables }\end{array}$} & \multirow{3}{*}{ Prediction sign } & \multicolumn{4}{|c|}{ AFR as a dependent variable } & \multicolumn{4}{|c|}{ ATR as dependent variable } \\
\hline & & \multicolumn{2}{|c|}{ Column 1} & \multicolumn{2}{|c|}{ Column 2} & \multicolumn{2}{|c|}{ Column 3} & \multicolumn{2}{|c|}{ Column 4} \\
\hline & & coefficient & $p$-value & coefficient & $p$-value & coefficient & $\mathrm{p}$-value & coefficient & $\mathrm{p}$-value \\
\hline Konstanta & & 0.0456 & $0.000^{\star * *}$ & -0.0457 & $0.000^{\star * *}$ & 0.0407 & $0.000^{\star \star *}$ & 0.0407 & $0.000^{\star \star \star}$ \\
\hline ATR & + & 0.1704 & $0.000^{\star * *}$ & 0.1696 & $0.000^{* * *}$ & - & - & - & - \\
\hline AFR & + & - & - & - & - & 0.0851 & $0.000^{* * *}$ & 0.1096 & $0.000^{\star \star \star}$ \\
\hline FAM & $+/-$ & -0.0678 & $0.000^{* * *}$ & -0.0674 & $0.000^{* * *}$ & -0.0068 & $0.021^{* *}$ & 0.0076 & $0.012^{* \star}$ \\
\hline ATR $^{*} \mathrm{FAM}$ & $+/-$ & - & - & -0.1676 & $0.046^{\star *}$ & - & - & -0.0788 & $0.025^{\star \star}$ \\
\hline AFR*FAM & $+/-$ & - & - & - & - & & & & \\
\hline$\triangle \mathrm{MVE}$ & + & 0.0094 & $0.000^{* * *}$ & 0.0095 & $0.000^{* * *}$ & - & - & - & - \\
\hline EPRESS & + & -0.0002 & 0.941 & -0.0003 & 0.913 & - & - & - & - \\
\hline$\triangle \mathrm{CFO}$ & + & 0.0429 & $0.000^{\star * *}$ & 0.0428 & $0.000^{\star \star *}$ & - & - & - & - \\
\hline PTROA & + & - & - & - & - & -0.0019 & 0.896 & -0.0021 & 0,380 \\
\hline NOL & - & - & - & - & - & -0.0002 & 0.932 & -0.0001 & 0.687 \\
\hline FOREIGN & + & - & - & - & - & 0.0047 & $0.058^{*}$ & 0.0047 & $0.019^{\star *}$ \\
\hline SIZE & + & 0.0094 & $0.035^{\star \star}$ & 0.0092 & $0.037^{\star *}$ & 0.0019 & 0.671 & 0.0021 & 0.983 \\
\hline LEV & + & 0.0311 & $0.014^{\star \star}$ & 0.0314 & $0.012^{\star \star}$ & -0.0104 & 0.164 & -0.0105 & $0.017^{\star \star}$ \\
\hline GDP & - & -0.0240 & $0.048^{\star *}$ & 0.0048 & $0.001^{* * *}$ & -0.0003 & 0.528 & -0.0003 & 0.633 \\
\hline STR & - & - & - & - & - & 0.1320 & $0.000^{\star \star \star}$ & 0.1541 & $0.000^{\star \star \star}$ \\
\hline INPROTECT & + & -0.0147 & $0.000^{\star * *}$ & -0.0148 & $0.000^{\star * *}$ & - & - & - & - \\
\hline \multicolumn{2}{|c|}{ Adjusted $\mathrm{R}^{2}$} & \multicolumn{2}{|c|}{0.1243} & \multicolumn{2}{|c|}{0.1580} & \multicolumn{2}{|c|}{0.0814} & \multicolumn{2}{|c|}{0.1193} \\
\hline \multicolumn{2}{|c|}{ Prob F-test } & \multicolumn{2}{|c|}{0.0000} & \multicolumn{2}{|c|}{0.0000} & \multicolumn{2}{|c|}{0.0000} & \multicolumn{2}{|c|}{0.0000} \\
\hline \multicolumn{2}{|c|}{$\mathrm{N}$} & \multicolumn{2}{|c|}{11,418} & \multicolumn{2}{|c|}{11,418} & \multicolumn{2}{|c|}{11,418} & \multicolumn{2}{|c|}{11,418} \\
\hline
\end{tabular}

*** significant at $\alpha=1 \%$, ** significant at $\alpha=5 \%$, *significant at $\alpha=10 \%$

AFR: aggressive financial reporting; ATR: aggressive tax reporting; FAM: family ownership; $\triangle M V E$ : change in market value of equity; EPRESS: earnings pressure in the form of a decrease in profit,; $\triangle C F O$ : change in cash flow; PTROA: pretax rate of return on investment; NOL: company losses; FOREIGN: foreign income; SIZE: company size; LEV: company leverage; GDP: per capita gross domestic product; STR: statutory company tax rate; INPROTECT: investor protection. 